\title{
Study on the Cultural Construction of Excellent Universities Based on the Core Competence
}

\author{
Xin Gao \\ Northeast Dianli University \\ Jilin City, Jilin Province, 132012
}

\begin{abstract}
In the 1990s, higher education in our country entered into the stage of popularized education. In the process of upgrading and expanding, the assimilation trend of disciplinary structure and cultural construction of institutions of higher learning was enhanced. Education is, in reality, a cultural activity. University culture is the "soul" and the core competence of the university. Faced with a new round of education reform, only by cultivating excellent university culture and enhancing the core competence can we win a place in the fierce competition.
\end{abstract}

Keywords-university culture; excellent university culture; core competence

\section{INTRODUCTION}

Since opening up to reform, with the rapid economic and social development, China's higher education has made great progress. In the $1990 \mathrm{~s}$, higher education in our country entered into the stage of popularized education. With a rapid development, the comprehensive universities have cultivated a great number of talents for enhancing the comprehensive national strength and participating in international competition. In the meantime, disciplinary structure and cultural construction of institutions of higher learning show a trend of assimilation. In the struggle of creating a top-notch university, competition in educational resources and the education market among institutions of higher education is intensifying. How to enhance its core competence and expand its reach is a primary task facing the theoretical workers and managers of colleges and universities.

\section{ON THE CORE COMPETENCE OF COLLEGES AND UNIVERSITIES}

The word "core competence" firstly proposed by Prahalad and Hamel refers to the capacity that is formed in the operation process of the enterprise. It can bring excess profits and is not easily imitated by the competitor, it is latterly used in a variety of industries and fields. In the complex competitive environment, most companies will focus on changes in the external environment. It is stressed by the core competence theory that enterprises shall also be more concerned about their own unique resource superiorities, thus to form the core competence different from other enterprises. The core competence theory is also known as the "theory of enterprise quality". With increasingly fierce competition among international and domestic institutions of higher learning, the "core competence" is gradually introduced to the category of higher education.

In the era of the knowledge-driven economy, the essence of competition among countries is the competition of talents, while the colleges and universities are the cradles for talent cultivation. There are numerous factors for the formation of the competence of a university, which are generally divided into two categories: teaching hardware conditions (i.e. material level) and university culture soft power. Campus physical space, various equipment, campus environment and so on are necessary hardware facilities of the university. With the growth in material wealth in the economic society, significant improvement on the teaching technologies and teaching methods, comparative campus construction and teaching facilities of the university, the difference in the material conditions is in a non-dominant position in the competition. While a larger difference lies in historical tradition, cultural heritage and other spiritual and cultural fields; the spiritual culture is in a dominant position in the competition of universities. Education is, in reality, a cultural activity. University culture is the "soul" and the core competence of the university. So to speak, the competition of colleges and universities is actually the competition of culture.

The core competence of institutions of higher learning is the cultural and historical heritage and tradition formed in the long-term development process of such a university, the sum of internal behavior paradigm, reflecting on the school spirit, teaching style, humanistic quality and other aspects. This competence is unique and hard for other competitors to imitate; compared with other capacities, this competence is the capacity at the core and dominant position. Only with enriched cultural connotation of colleges and universities, enhanced cultural tastes, cultivated outstanding culture manifesting their own characteristics and improved core competence can a university win the competition of the education market.

\section{CHARACTERISTICS AND MISSION OF THE UNIVERSITY CUlture}

Impacted by various ideological trends and cultures in society, the university culture is the distribution center of social cultures, and all kinds of ideas and thoughts are 
reflected on campus. The university is where talents gather, forming a culture different to the common customs, the cradle of advanced cultures featuring advancement. With the social development and changing of times, universities have undertaken more missions for the cultural construction of the society - cultural inheritance, integration, and innovation. In April 2011, Mr. Hu Jintao pointed out in his speech at Tsinghua University's 100th anniversary that "higher education is an important carrier for the inherence of outstanding culture and an important source for ideological and cultural innovation", "for comprehensively improving the quality of higher education, we must vigorously promote the cultural heritage and innovation."(1)

\section{A. Advancement Characteristic of University Culture}

The purpose of college education is "preaching, teaching and dispelling doubt". In the final analysis, the dissemination of scientific and cultural knowledge, edification and influence of ideology and cultivation of values are mental activities - not driven by economic benefits, and with no direct utilitarian target but a strong technicality and ideality.

In the Chinese Confucian culture, university is where adults come to study early on; it provides a place for the process of the moral development of the talent needed to become a gentleman. A strong academic atmosphere and large numbers of academic research achievements are the important characteristics of college education, unlike other educations. The advancement of university reflects on the scientific spirit, methods and thinking. Differing from the secular culture, culture of enterprise and other organizations, the college education plays the role of guiding and leading the social culture - the reason is that the cultural level of the main crowd at university is higher, and has a scientific value orientation. University is a source of national culture, and leading culture is the historical responsibility of university. Recalling the history of our country, the May Fourth Period are the years of conflict of the old and new cultures, during which countless young students hold high the banner of democracy and science, fully reflecting the leading role of university culture. At the same time, the college days are a period in which youthful students let their dreams fly - it is key for the cultivation and formation of life values. University education helps students establish a view of life, values and the world. Thought nurture is beyond the thought level of the realistic society. Technicality and ideality of college education and activities are the specific reflections of cultural advancement of the university.

\section{B. Mission of University Culture - Inherence and Innovation}

Ruth Benedict, contemporary American cultural anthropologist, divided culture into "quilt culture" and "shame culture" according to its characteristics. "Quilt culture" means that in highly religious western countries, people will instinctively restrain themselves following the

${ }^{(1)}$ The important address of President Hu Jintao at Tsinghua University's 100th anniversary, April 2011 religious (God) creeds. Once breached, even if nobody finds out, they will blame themselves with a sense of sin in their inner heart. The main feature of this type of culture is to advocate the establishment of an absolute moral standard to restrain the human heart. In China, people care more about how people around them think, evaluate and treat them, characterized by forced self-restraint relying on others, i.e. the external force. Chinese and Japanese so called 'shame culture' was believed by Benedict to be based on eastern Confucian culture, and stressed a "sense of propriety, justice, honesty and honor" at its essence. Comparing two types of culture, shame culture relies strongly on the exterior and has a lack of restriction mechanism and power; once the external constraining force disappear, it may lead to social deformity. At present, China is in the period of social transformation, with complex surging currents of thought the shame culture faces the dilemma of value diversification. If there is no firm belief and faith as a support, it is likely to cause serious social problems. The social and cultural construction still has a very long way to go. As the cradle of advanced culture, university education shall have the unavoidable responsibility to become a main force. It is also a new mission of university "cultural inheritance and innovation" under the new situation. The cultural function of university lies in inheritance in the first place, which is to inherit historical and ideological quintessence. Traditional Chinese culture owns countless treasures, yet they are getting lost in the fast revolution, "loyalty, filial piety, kindheartedness and justice" and "honesty, manners, wisdom and bravery" can only be seen on the street boards in Taipei; the sense of responsibility in "chivalrous gallantry" and "every common man has his obligation" has been submerged by "don't wanna grow up" and the infinite extension of adolescence. Poetry, calligraphy and painting have become a luxury pursuit... Excellent traditional culture should be inherited and promoted, university culture should appropriate lost property in its development, and the study of Chinese ancient civilization should be a required course for contemporary university students.

Certainly, cultural inheritance does not equal to cultural retro, we should absorb the quintessence and avoid total and uncritical acceptance. In September 2002, a research institute committing to university cultural construction was jointly established by Tsinghua University, Peking University and Higher Education Press, which is a solid start for promoting the studies of university culture. Cultural inheritance and innovation is a new mission endowed by our age on universities; it is a driving force for university development and also an important spiritual support of national progress.

\section{Character and Morals of University Culture - Cultural Personality}

In order to adapt to the needs of talent arising from the rapid development of the economy and society, higher education in our country is marching towards popularized education at a fast pace. Numerous academies are eager to upgrade by setting up a large number of new majors and expanding their enrollment scale, colleges ask for an 
upgrade to universities and universities ask for an upgrade to comprehensive universities, so in this way school-running orientation is blurred; "subject and major setup lags behind the needs of social development, colleges are of no difference". The phenomena of lacking school-running characteristics, convergence of university culture and cultural weakening are getting increasingly serious. By conclusion, it can be seen that the reasons come from various aspects. On the one hand, China's economic, political and cultural system has undergone profound changes ever since the reform and opening-up, the establishment of market economic system links up people's every act with economic interest and school-running goals are getting increasingly utilitarian, which diverges from the original intention of colleges and universities, resulting in educational and academic corruption occurring repeatedly. On the other hand, the accumulative trend of economic globalization challenges traditional values and peoples' ideology; lifestyles are experiencing changes, secular ideology greatly impacts campus culture, and decadent culture like money worship and hedonism are breeding. Humanist spirits are sliding downhill.

The essential characteristic of a contemporary excellent university is cultural personality. Throw our eyes back on the world famous universities; all of them have a clear and relatively stable educational concept without exception - a school that lacks a genuine motto can never become outstanding. The motto of Harvard University, "Let Plato be your friend and Aristotle, but more let your friend be truth" is profound and meaningful, which represents the traditional humanistic spirits of America and the idea of upholding both tradition and the pursuit of truth - as well as paying high attention to the quality of education. Being the cradle of Nobel Prize laureates, Harvard has trained numerous talents in the field of literature, medical science, law and business, and it has always been a flagship in world colleges and universities. The motto of University of Oxford "Dominus Tlluminatio Mea" (Latin) means "The Lord is My Illumination", quoted from Psalm 27 of The Bible. The early moral and ideological education of European countries took "The Bible" as a reference book, and even in present day religious education is still performing special functions of ideological, political and moral education in European countries.

It is easy to see that students from the same school always carry certain common cultural traits, while students cultivated by universities with different cultural deposits often exhibit diverse temperament, taste and spirit. This is hard for other universities to imitate, and best reflects the traits of an excellent university. Only by maintaining distinctive culture can a university occupy advantages in the fierce competition at the source of students.

\section{STRENGTHENING THE CONSTRUCTION OF UNIVERSITY Culture, ENHANCING THE CORE COMPETENCE}

The educational reform in our country takes modern vocational education as a breaking point, and training technical talents as the major objective in order to adapt to the needs of social development and solve the structural contradictions of employment. The Ministry of Education has cleared the reforming direction: $50 \%$ of 1,200 national ordinary institutions of higher learning will shift to vocational education. Under the new situation, institutions of higher learning can only win advantages by adjusting development strategy, strengthening cultural construction, cultivating university culture and building brands.

\section{A. Accurate Orientation of University, Clear Thinking for Running a University}

According to subject characteristics, and the proportion of subjects in the university, existing universities are broadly divided into comprehensive universities, colleges of letters, and science and professional universities. According to the scientific research scale, they are divided into teaching type, teaching-research type, research type and research-teaching type. In order to expand enrollment and pursue upgrade, many institutions blindly set up new specialties, but the teachers are not qualified and teaching materials are poor, which seriously affects the talent cultivation and leads to unclear positioning of the university. Teaching is the basic function for the birth and existence of a university - imparting knowledge and educating students. The relationship among teaching, research, social service and cultural inherence and innovation must be handled correctly. The path of connotative development must be followed. Without the strength of a comprehensive university, or the conditions of a research type university, a breakthrough can be made according to a university's own reality selectivity; an advantage must be formed instead of simply managing different disciplines by means of "universal application".

Formulae scientific management systems and standardize teacher assessment methods: At present, in most colleges and universities, "scientific research projects, quantity of paper and prizes" are taken as the rigid indexes for the assessment of teachers. They are targeted to improve the scientific research level, but ignore the first function of the colleges and universities - teaching; making light of student services and cultivation will turn the educational purpose upside down. Comparatively speaking, university cultural management needs to pay more attention and time to the long cycle; the short-term effect is less than the rigid performance. However, it is a compulsory course of school management.

Expand the horizon: By learning from the positioning of eclectic universities overseas, our universities can make appropriate positioning so as to adapt to the demand of economic and social development. American Higher Education, written by the former principal of Harvard University, enumerates multifarious universities in America, such as large scale universities, small scale colleges, public and private universities, professional colleges and colleges of letters and science, etc, as well as college specially for male or female; Wellesley College is a private, prestigious women's college. There are also some community colleges. Comprehensive university is absolutely not a target for universities and colleges to pursue, but the university positioning needs sober analysis and judgment. Relatively, 
vocational orientation of professional universities is clear. In the first half year this year, the Reform of China's Ministry of Education has a clear direction. Vocational skill training is placed in the first place, which will attract more attention in the reform of the educational system.

\section{B. Manifesting the Featured University Culture, Strengthening the Function of Culture Education of University}

It was proposed in the "Outline of Medium and Long Term Educational Reform and Development of the County (In 2010-2020)" that: "Lead the universities and colleges to position reasonably, overcome the homogeneity tendency, form their own theory and style on school management, show characteristics at different levels in different areas, and race to the top." "Featured school management" firstly appeared in the national strategic documents.

In the era of knowledge-driven economy, knowledge industry has become the most important production sector. As an important mechanism to disseminate knowledge and explore new knowledge, universities have become the core of the knowledge industry. China is in an era witnessing the blend and collision of Chinese and Western cultures. Chinese university culture carries the historical mission of inheriting outstanding traditional culture and blending diverse cultures, as well as cultivating its own university culture with distinct features so as to reflect the personalized features different from other universities. Each university has a different history and tradition, and its survival and development has its own unique style. Features can be combined with the regional culture; materialized on top of a variety of carriers, such as discipline, curriculum, ethos and motto. The more distinctive university materialized carriers are, the more obvious the distinctive culture will be.

\section{CONCLUSION}

Under the conditions of market economy, we must: correctly handle the relationship between higher education and the market economy, adhere to the attitude of serving society and university character, strengthen the role of the university culture in personnel training, standardize system culture, vigorously build the school culture, persist in the University's academic value-orientation, stick to the uniformity of scientific rationality and humanistic spirit, exert efforts to create a good academic environment and free academic atmosphere, and promote the transformation of academic achievements to the practice so that it may serve the real economy. We must carry forward the national spirit, and hold on to the correct direction and cultivate socialist modernization spirit. People must be influenced with noble culture, cultivated with excellent culture, and lead with advanced culture. The function of teaching must be enhanced at university. We must promote the development of ideological and ethical standards and scientific and cultural quality. All of the above is responsible for the cultural construction of colleges and universities.

\section{REFERENCES}

[1] Wang Jisheng et al., University Culture is Where Core Competence of Universities Lie [J], Higher Education Development and Evaluation, 2007(1).

[2] He Zujian et al., Harmony in Diversity, - Socialist Core Value System Leading the Integrated Research of University Culture [J], University Education Science, 2013(3). 